\title{
América do Sul: infraestruturas em regiões periféricas e tendências atuais
}

\section{South America: infrastructures in peripheral regions and current trends}

Rev. Bras. Est. Def. v. 5, nº 1, jan./jun. 2018, p. 329-361 DOI: 10.26792/RBED.v5n1.2018.75047

\section{ALDOMAR ARNALDO RÜCKERT CAMILO PEREIRA CARNEIRO}

\section{INTRODUÇÃO}

O presente artigo $^{1}$ apresenta uma análise de políticas territoriais direcionadas para infraestruturas de conexão em processos de integração sul-americana. Para tanto aborda-se três perspectivas relacionadas a este processo, principalmente a partir da criação da União Sul-Americana de Nações - Unasul: 1. o projeto da América do Sul como uma região geopolítica e suas assimetrias internas; 2. possíveis repercussões territoriais de projetos de redes de circulação em regiões periféricas; e, por fim 3. uma indagação sobre quais são os rumos atuais da integração sul-americana.

$\mathrm{Na}$ primeira perspectiva procura-se caracterizar os diversos regionalismos na América do Sul e o recente projeto da construção de uma região geopolítica. Ressaltam-se na região as assimetrias socioeconômico-territoriais entre os países, principalmente entre Brasil e seus vizinhos. $\mathrm{Na}$ segunda perspectiva procura-se responder com três estudos de caso de que maneira alguns projetos de infraestruturas de conexão, a maioria pertencente a projetos da Unasul/Conselho Sul-Americano de Infraestrutura e Planejamento - Cosiplan têm repercutido em regiões periféricas na Argentina, Bolívia e Região das Guianas. ${ }^{2}$

Por fim, na terceira e última perspectiva apresenta-se elementos para caracterizar os rumos atuais da proposta da América do Sul como uma região geopolítica e das infraestruturas de conexão, fortemente condicio-

Aldomar Arnaldo Rückert - Doutorado em Ciências: Geografia Humana - pela Universidade de São Paulo.

Camilo Pereira Carneiro - Professor Doutor Visitante no Programa de Pós-Graduação em Fronteiras e Direitos Humanos da Universidade Federal da Grande Dourados (UFGD). 
nados à crise mundial pós-2008 e pelo governo Temer, que assumiu a presidência do Brasil através de um golpe parlamentar em 2016.

Nos três casos escolhidos, na Bolívia, na Argentina e na Região das Guianas procurou-se evidenciar exemplos de regiões diferenciadas entre si quanto às suas localizações em espaços naturais distintos: as Guianas na floresta Amazônica oriental, a região de Cuyo na Diagonal Desértica na pré-cordilheira dos Andes na província de San Juan, Argentina e o Território Indígena e Parque Nacional Isiboro Sécure - Tipnis - na transição Andes / floresta amazônica entre os departamentos de Cochabamba e Beni na Bolívia. Os três casos escolhidos têm como pontos em comum não apenas as baixas dinâmica econômica e densidade demográfica, mas também a sua localização em espaços periféricos distantes dos grandes centros urbanos e dos principais corredores de circulação.

Além disso, os casos escolhidos são significativos em si mesmos, visto que no exemplo do Corredor Bioceânico Porto Alegre (Brasil) - Coquimbo (Chile) a Ruta Nacional 150 (no Eixo Mercosul-Chile da IIRSA-Cosiplan), na Província de San Juan (Argentina), é muito significativa por tratar-se do último elo de ligação a completar-se antes do início dos trabalhos de construção do túnel Água Negra nos Andes. O caso de Tipnis, na Bolívia, por sua vez, reflete a reação das comunidades tradicionais na defesa de seus direitos territoriais e contra a construção de uma rodovia que poderá cruzar o território indígena. Já o caso de rodovias precárias no Planalto das Guianas e o baixo investimento recebido até o momento podem refletir o isolamento entre os Estados nacionais na região além das próprias características da região que é ocupada, predominantemente, no litoral, estando o interior amazônico relativamente isolado e com deficiências de infraestruturas. A abertura extraoficial (uma iniciativa dos prefeitos de Oiapoque e Saint-Georges, sem a presença dos presidentes dos países) para o trânsito de veículos apenas entre as duas cidades, da ponte internacional Brasil-Guiana Francesa, por exemplo, sobre o rio Oiapoque, no ano de 2017, pouco contribui para alterar o cenário de isolamento entre os Estados nacionais da região, visto as várias restrições, por exemplo, que a França metropolitana impõe à entrada de brasileiros na Guiana Francesa.

Analisar políticas territoriais através dos usos políticos do território como projeções de poder e controle territorial (Sanchez 1992) ${ }^{3}-$ em processos integracionistas através de redes de circulação - infraestruturas de conexão supranacional - permite-nos enfocar como agem conjuntos de atores territoriais e como estas ações podem repercutir territorialmente. Além disso, trata-se de conhecer as estratégias e os recursos que cada ator ou conjunto de atores, em suas diversas escalas de poder e gestão, mobilizam para atingir seus objetivos (Raffestin 1993; Rosière 2007). Os usos 
políticos do território e ações públicas territoriais de Estados nacionais, governos regionais, da UNASUL e da IIRSA-Cosiplan, através de diferentes escalas de poder e gestão compartilhadas entre diferentes níveis de governos podem - ou não - estar associados a repercussões territoriais que, por sua vez, podem se constituir como novas questões para análise territorial. Para tanto, adota-se uma perspectiva de que o espaço geográfico é descontínuo o que se revela significativo na América do Sul.

No cenário sul-americano, as regiões periféricas (em oposição às regiões e pontos nodais centrais via de regra localizadas nas regiões costeiras) podem ser compreendidas como fraturas e descontinuidades, com fortes desigualdades territoriais em cenários nacionais e supranacionais, com baixas densidades de capital, populacionais, técnicas e informacionais e com pouca fluidez nas circulações, o que foi definido por Santos e Silveira (2003) como espaços opacos. As localizações distantes de regiões periféricas em processos de integração supranacionais tendem a ser relativizadas (o espaço se torna relativo quando as distâncias podem diminuir pelo aumento da fluidez da circulação) com a implantação e/ou melhorias de novas redes de circulação - quando houver investimentos - principalmente em regiões fronteiriças. Importante ter em conta que o processo de criação de fluidez, como lembram Santos e Silveira (2003) é seletivo e não-igualitário, pois as regiões onde se situam produções destinadas à exportação e ao comércio distante têm prioridade nesses equipamentos da infraestrutura estratégica.

Em regiões fronteiriças, quando coexistem médias ou altas densidades de capital, técnicas e populacionais em ambos os lados dos Estados nacionais há a possibilidade de surgirem processos de transfronteirização, isto é, articulações e conexões supranacionais que podem abranger desde a vida cotidiana das populações até a implantação de infraestruturas que possibilitam as conexões transfronteiriças. Este é o caso do Eixo Mercosul-Chile, onde estes indicadores coexistem com uma vida de relações transfronteiriças intensas. Por outro lado, onde as regiões fronteiriças são espaços opacos $e$ distantes dos centros políticos ou econômicos, a fluidez para o interno e externo pode inexistir, tendendo para situações de periferias extremas desconectadas de processos de integração e transfronteirização. Este é o caso da rodovia projetada para passar através de Tipnis, localizada em uma região interiorana entre os departamentos de Cochabamba e Beni, Bolívia, bem como da Região das Guianas, vasta região com povoamento litorâneo e infraestruturas interiores precárias.

A Unasul, ao incorporar a IIRSA-Cosiplan ao seu leque de ações em escala sul-americana, em 2011, apontou para multiescalaridade dos processos de integração. Com cita Scheibe (2013) a IIRSA é um conjunto de ferramentas com incidência em múltiplas escalas. Dietz (2008), por sua 
vez, já havia identificado a complexidade do “entrelaçamento" das diversas escalas de poder e gestão envolvidas em projetos da terceira ponte Brasil-Argentina da então IIRSA, as escalas supranacionais representadas pelas áreas de abrangência da Iniciativa e também do MERCOSUL, escalas nacionais (Brasil e Argentina), regional transfronteiriça de federações econômicas de comércio e fóruns políticos regionais conjuntos bem como as escalas subnacionais (estados e províncias ou departamentos) e a local/ regional com as cidades gêmeas, por exemplo. Estes "entrelaçamentos" das diversas escalas de poder e gestão estão presentes, em medidas diversas, em projetos de integração física estimulados e apoiados pelo Cosiplan.

O desenvolvimento deste artigo contou com sucessivas abordagens ao problema de pesquisa em várias etapas de investigação durante o projeto em curso "Transfronteirizações na América do Sul” após 2014. ${ }^{4}$ Foram realizados trabalhos de campo em duas das três regiões mencionadas neste período na Diagonal Desértica sul-americana na região de Cuyo, Argentina, províncias de Mendoza e San Juan, bem como na Região das Guianas, entre Macapá (Amapá, Brasil), Paramaribo (Georgetown e Lethem) e Bonfim e Boa Vista (Roraima, Brasil). As explorações de campo consistiram em observações das infraestruturas nessas regiões com registros fotográficos e documentais bem como através de entrevistas semiestruturadas com moradores dessas regiões. Já o caso de Tipnis foi observado somente através de informações em fontes secundárias.

Seguem os três tópicos que procuram aprofundar as perspectivas de análise. Em primeiro lugar aborda-se o projeto da América do Sul como uma região geopolítica na transição do velho regionalismo (1950-1970), do regionalismo aberto (anos 1990) ao regionalismo pós-neoliberal (2000). Procura-se também caracterizar neste primeiro tópico as assimetrias territoriais entre o Brasil e os países vizinhos, suas fraturas e descontinuidades. Em segundo lugar procura-se trazer algumas observações de como projetos de infraestruturas de conexão podem repercutir em regiões periféricas através de três exemplos já citados: na Bolívia, na Argentina e na Região das Guianas. Por fim, seguem considerações sobre os rumos atuais da integração sul-americana e das infraestruturas de conexão, cenário onde percebe-se, atualmente, uma relativa ausência de continuidade do ideário da América do Sul como uma região geopolítica. 


\section{O PROJETO DA AMÉRICA DO SUL COMO UMA REGIÃO GEOPOLÍTICA}

O projeto da América do Sul como uma região geopolítica pode ser compreendido como uma inovação territorial no subcontinente, uma das mais importantes após o fim da Guerra Fria. No âmbito do ideário da América do Sul como uma região geopolítica, "isto é, uma entidade política transnacional dotada de unidade mínima e arcabouço institucional baseados em princípios e macro objetivos comuns nas relações internacionais" (Costa 2009) encontra-se em vários países do subcontinente nos anos 2000, uma nova política externa de vários governos populares ${ }^{5} \mathrm{ou}$ progressistas especialmente com a expressiva liderança do governo Lula da Silva, do Brasil, que passou a ocupar grande destaque no cenário geopolítico da região continental.

Após as formulações da Comissão Econômica para a América Latina - CEPAL através do velho regionalismo (anos 1950-1970) e do regionalismo aberto alinhado ao Consenso de Washington (anos 1990) seguiu-se a formulação do regionalismo pós-neoliberal sul-americano pelos governos populares com ações diplomáticas que resultaram na criação da CASA - Comunidade Sul-Americana de Nações, em 2004, em Cuzco, Peru. Posteriormente rebatizada, a CASA foi transformada na União SulAmericana de Nações - Unasul (23 de maio de 2008, Brasília) definida como um espaço multilateral de coordenação política, um instrumento de governança regional, englobando a ALBA - Aliança Bolivariana para os Povos da Nossa América, a CAN - Comunidade Andina - , o Mercosul e a Aliança do Pacífico (ver mapa 1).

Com importante foco na busca pela redução das assimetrias regionais, no alinhamento com os países em condições socioeconômicas relativamente semelhantes no BRICS (Brasil, Rússia, Índia, China e África do Sul) e nas novas relações Sul-Sul, a Unasul avançou rumo a mudanças nas concepções geopolíticas da América do Sul. Passou-se a reconhecer a importância do comércio, mas agregaram-se fatores estratégicos como segurança, solução de conflitos, defesa dos direitos humanos, vigência da democracia, desenvolvimento socioeconômico, proteção ao meio ambiente e integração física e energética. Ressalte-se, porém, que a região se caracteriza por profundas assimetrias territoriais que passaram a constar no ideário do Cosiplan sob o tema do desenvolvimento regional, visto que o cenário regional é muito complexo e acumula séculos de desigualdades socioterritoriais. Porém, o próprio projeto do Cosiplan depende de investimentos que podem demorar a ocorrer, tendo em vista o cenário de crise global pós-2008. 


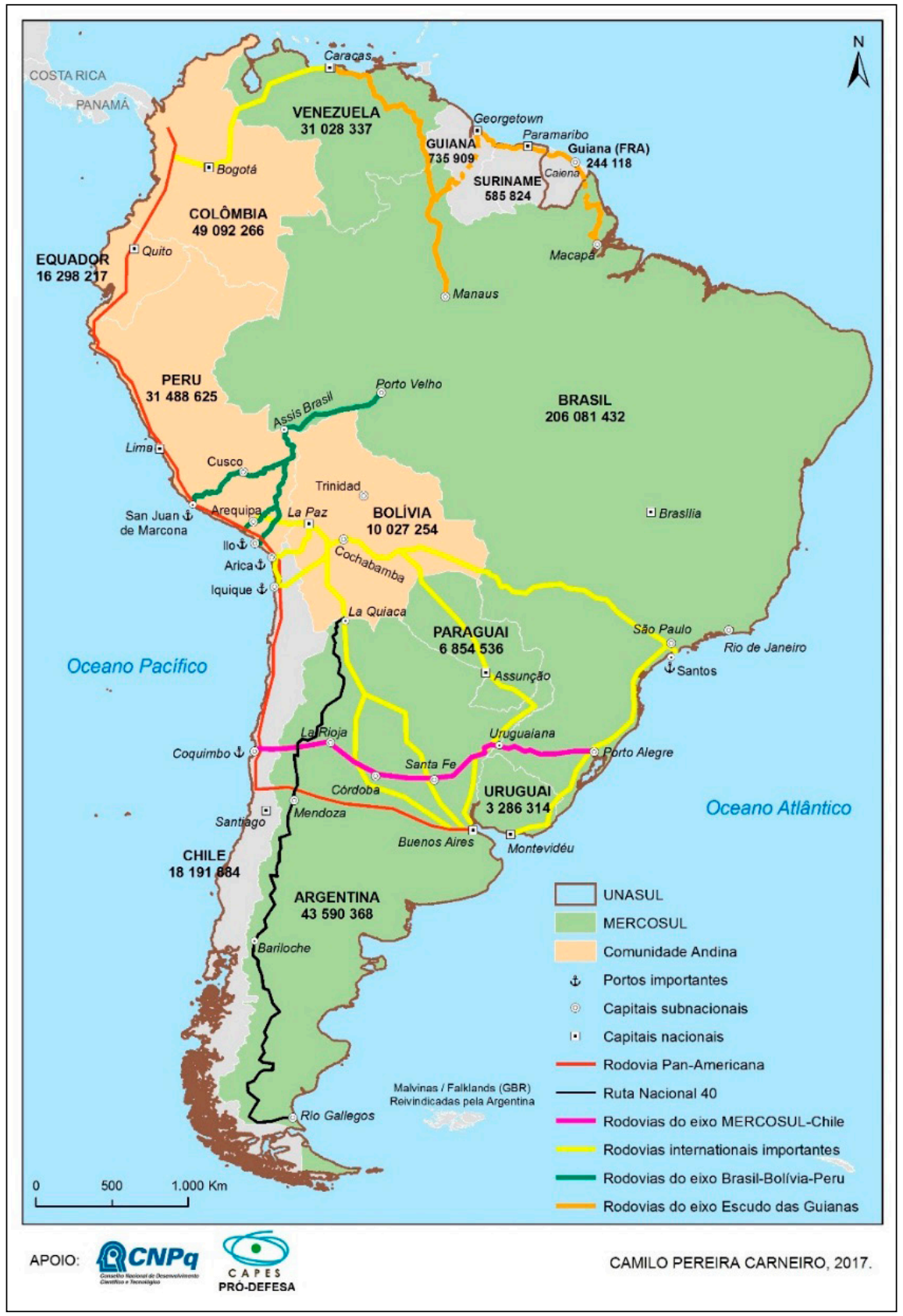

Mapa 1 - América do Sul: um projeto de região geopolítica. 


\section{As assimetrias territoriais entre Brasil e América do Sul: fraturas e descontinuidades}

A região América do Sul é, no plano interno, um território fortemente assimétrico, caracterizado por fraturas e descontinuidades socioeconômicas. A riqueza produtiva agrícola e industrial e as melhores condições de vida da população concentram-se nas regiões litorâneas, as regiões core, enquanto que baixos indicadores de PIB e de IDH encontram-se dispersos por vastas regiões periféricas interioranas.

Dados do Banco Mundial para 2016 atestam as grandes disparidades dos valores do Produto Interno Bruto entre o Brasil e seus vizinhos. ${ }^{6}$ A Bolívia, por exemplo, é um dos países mais pobres da América do Sul, com IDH médio de 0,674 (2015), juntamente com o Paraguai (IDH médio de $0,693,2015$ ). Em 2014, 45\% da população da Bolívia (que totalizava 10.631.490 habitantes) encontrava-se abaixo da linha de pobreza (Index Mundi). As assimetrias entre Bolívia e Brasil revelam-se, igualmente, nos fluxos migratórios: um expressivo crescimento do número de cidadãos bolivianos que emigraram - quase 150.000, segundo dados da Polícia Federal brasileira - para o Brasil num curto período de seis anos, entre 2008 e 2014 (Uebel 2015).

No plano do comércio intrarregional, dados da Associação LatinoAmericana de Integração - ALADI - demonstram que as exportações do Brasil para os países da América do Sul no período 2002-2016 aumentaram seis vezes, tendo passado de US $\$ 7,4$ bilhões para US $\$ 45,2$ bilhões em 2011, sendo Argentina, Chile e Venezuela os principais países importadores. As principais importações pelo Brasil do conjunto dos países vizinhos, por sua vez, cresceram pouco mais de duas vezes entre 2002 e 2016, passando de US\$ 8,09 bilhões em 2002 para US $\$$ 19,43 bilhões em 2016, sendo que Argentina, Chile e Bolívia são os países que mais exportam para o Brasil.

Os fluxos de cargas rodoviárias de exportação/importação entre o Brasil e os países vizinhos pelo modal rodoviário concentram-se na região transfronteiriça da Bacia do Prata/Eixo Mercosul-Chile que apresenta uma malha complexa de infraestrutura, no núcleo geoeconômico que se caracteriza como uma diagonal que se estende do sudeste e sul do Brasil (estados industrializados de Minas Gerais, Rio de Janeiro, São Paulo, Paraná, Santa Catarina e Rio Grande do Sul), sul do Paraguai e província de Buenos Aires, alongando-se ao centro da Argentina, Chile até o Pacífico. O percentual de estradas não pavimentadas na América do Sul é de aproximadamente $50 \%$, o que faz com que o transporte terrestre eleve o custo comercial (Bown et al, 2017). 
As principais conexões viárias internacionais do Brasil concentram-se na Bacia do Prata - são 23 cidades gêmeas com Bolívia, Paraguai, Argentina e Uruguai - sendo 32 ao longo de todas as fronteiras internacionais do país com os vizinhos. Cabem às cidades gêmeas de Uruguaiana $(\mathrm{BR}) / \mathrm{Paso}$ de los Libres (ARG), Foz do Iguaçu (BR)/Ciudad del Este (PY) e São Borja (BR)/Santo Tomé (AR) os principais volumes de tráfego de cargas nos sentidos de exportação / importação. O volume atingiu 374.710 caminhões registrados pela Associação Brasileira de Transportadores Internacionais (ABTI) junto à Receita Federal do Brasil no ano de 2016, correspondendo a $68 \%$ do total de 547.081 caminhões registrados em 16 cidades gêmeas na Bacia do Prata que possuem postos de alfândegas.

\section{REPERCUSSÕES DE PROJETOS DE INFRAESTRUTURAS DE CONEXÃO EM REGIÕES PERIFÉRICAS: TRÊS ESTUDOS DE CASO}

Dentre os projetos de infraestruturas de conexão (a maioria pertencente à carteira de projetos do Cosiplan e à Agenda de Projetos Prioritários de Integração - $\mathrm{API}^{7}$ ou a eles relacionados) apresenta-se três casos de infraestruturas de conexão em regiões periféricas: a) o projeto da rodovia Villa Tunari - San Ignacio de Mojos, através do Território Indígena e Parque Nacional Isiboro Sécure, Tipnis, Bolívia; b) a Ruta Nacional 150, no Corredor Bioceânico Porto Alegre (BR) e Coquimbo $(\mathrm{CH})$ e c) projetos de melhorias de estradas e pontes que interligam o Brasil, a Guiana Francesa, o Suriname e a Guiana na Região das Guianas e Floresta Amazônica, no Eixo Escudo das Guianas.

Os três casos de infraestruturas de conexão em regiões periféricas escolhidos para esta investigação refletem objetivos de pesquisas em curso em regiões fronteiriças e/ou transfronteiriças na Bacia do Prata e regiões adjacentes, bem como na Região das Guianas na Amazônia Oriental, procurando-se refletir sobre as distintas dinâmicas de processos de integração no norte e no centro-sul da América do Sul. O projeto da rodovia Villa Tunari - San Ignacio de Mojos, através do Território Indígena e Parque Nacional Isiboro Sécure, Tipnis, Bolívia - que localiza-se em região interiorana na floresta Amazônica, em posição intermediária entre os eixos Peru-Bolívia-Brasil e o Interoceânico Central, entre os departamentos de Cochabamba e Beni. Já a Ruta Nacional 150, no Corredor Bioceânico Porto Alegre (BR) e Coquimbo (CH) - Eixo Mercosul-Chile, que se localiza na região geográfica desértica de Cuyo e Sierras Pampeanas na Província de San Juan, Argentina, região tradicionalmente isolada que, recentemente, passou a interligar-se entre os pré-Andes e o Pampa Úmido, o Litoral e o Norte Argentino. Por fim, a rodovia Transguianense, no Eixo do Escudo 
das Guianas que se localiza em região periférica na Amazônia, onde a infraestrutura precária entre o estado do Amapá (BR), a Guiana Francesa, o Suriname, a Guiana, a Venezuela e os estados de Roraima e Amazonas (BR) reflete as ainda baixas densidades de interligações na porção da Amazônia oriental.

Como explicitado na Introdução, os casos aqui apresentados são importantes em si mesmos, tendo em vista se tratarem de regiões localizadas em espaços distantes e pouco conhecidos do "mundo exterior" na América do Sul. Mesmo que cada um dos casos seja diferente eles refletem, em seu conjunto, de certo modo, o status de transformações ou de imobilismos territoriais em relação aos projetos da IIRSA-Cosiplan. Tratados de forma conjunta, os três casos não apenas trazem realidades territoriais pouco estudadas como ilustram preocupações concernentes à necessidade de projetos de infraestrutura viária não apenas serem estradas que produzem "efeitos-corredor" mas que possam induzir transformações socioterritoriais importantes nos "grotões" da América do Sul. Neste sentido, entendemos que as três regiões, casos de estudos, fornecem informações preciosas para entender-se o que pode e o que não pode estar ocorrendo na região da América do Sul a partir de projetos de infraestrutura.

\section{A rodovia Villa Tunari - San Ignacio de Mojos}

Apesar de a Bolívia constar em sexto lugar quanto ao número de projetos do Cosiplan, o seu território é perpassado por cinco Eixos: Andino, Capricórnio, Hidrovia Paraguai-Paraná, Interoceânico Central e PeruBrasil-Bolívia, o que o caracteriza como um centro de coesão e dispersão de fluxos em escala continental (Pfrimer 2011). A participação de empreiteiras brasileiras com financiamentos do banco público brasileiro BNDES previstos durantes os anos 2000, como OAS e Odebrecht em obras do Cosiplan ou relacionadas aos eixos de integração provocou fortes reações anti-imperialistas contra sua presença no caso da rodovia Villa Tunari San Ignacio de Mojos nos departamentos de Beni e Cochabamba. O caso de Tipnis traz para o cenário da análise territorial a presença da tensão e do conflito envolvendo não apenas a escala do Estado da Bolívia e os atores indígenas locais, fortemente organizados, bem como o capital estatal do Brasil (via BNDES) e as empresas empreiteiras brasileiras. O conflito caracteriza relações de poder entre escalas de poder em que os indígenas e suas organizações tem resistido a projetos de integração física de rodovias.

O conflito da construção da rodovia Villa Tunari - San Ignacio de Mojos que poderá atravessar o Território Indígena e Parque Nacional Isiboro Sécure, Tipnis, com 1,2 milhão de hectares, localizado nos depar- 
tamentos de Beni e Cochabamba (ver mapa 2), é um caso exemplar do sentimento popular anti-imperialista brasileiro e da não aceitação de projetos do Cosiplan e obras relacionadas pelas populações locais. Após vários conflitos em 2011, durante a $8^{\mathbf{a}}$ Marcha Indígena a La Paz, seguiram os cancelamentos dos contratos com a construtora brasileira OAS e do financiamento de exportação de bens e serviços do BNDES, após denúncias de organizações da sociedade civil junto ao banco sobre diversas irregularidades ambientais e violações de direitos territoriais indígenas (Fonseca, Mota 2013; Conectas 2015). A foto 1 retrata o portal de entrada da Bolívia na cidade de Puerto Quijarro, a partir de Corumbá, Mato Grosso do Sul.

Apesar das concessões de Evo Morales aos movimentos indígenas, as obras da rodovia foram retomadas por empresas bolivianas em $2013 \mathrm{em}$ trechos fora do território Tipnis. Em 2015, uma unidade de engenheiros militares da Bolívia e da Venezuela deu continuidade às obras em segmentos fora do parque (Carwil 2015). Afirmou Morales sobre a estrada: "Em primeiro lugar ela vai liberar o departamento de Beni. Em segundo lugar haverá uma maior integração entre os departamentos, estamos convencidos disto, trata-se de projetos macro nesta região" (Ariñez 2015). A retomada das obras passou a ser contestada novamente pela Sub-Central dos Povos Indígenas de Tipnis. As mulheres indígenas rechaçaram de forma categórica a construção da rodovia, declarando estado de emergência e mobilização contínua contra a afronta permanente do governo da Bolívia (Pronunciamento Público 2017). Embora o governo de Evo Morales, mesmo com forte apoio de movimentos sociais indígenas, tenha adotado um enfoque pragmático para procurar conectar regiões periféricas a eixos principais de circulação, a resistência indígena demonstrou que este projeto - e mesmo a pauta da integração sul-americana - não faz sentido para estes povos tradicionais.

\section{O Corredor Bioceânico Porto Alegre (Brasil) - Coquimbo (Chile) no Eixo Mercosul-Chile}

O Eixo Mercosul-Chile articula o sudeste e sul do Brasil aos países vizinhos prolongando-se a Santiago do Chile através do Passo dos Libertadores nos Andes (ou Passo Cristo Redentor), entre a Província de Mendoza-AR e a Província Los Andes - IV Região do Chile. O Passo está em uso desde 1980 e se caracteriza por intensos fluxos de transportes de cargas - um importante indicador de transfronteirizações e fluidez territorial - que interligam o mercado brasileiro aos portos do Chile. 


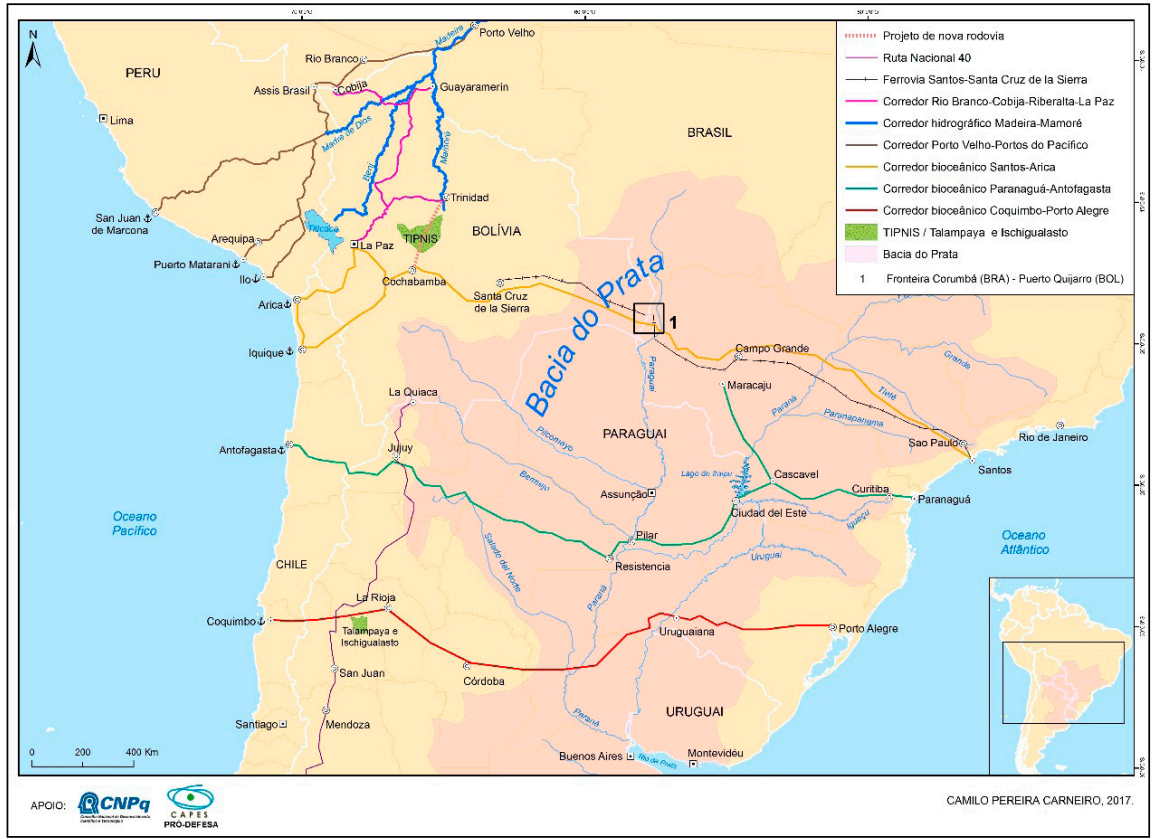

Mapa 2 - Corredores bioceânicos nos eixos Central e Mercosul-Chile, com as localizações do projeto da rodovia Villa Tunari - San Ignacio de Mojos (Tipnis, Bolívia) e Ruta Nacional 150 na Argentina, com a localização dos parques naturais Talampaya e Ischigualasto.

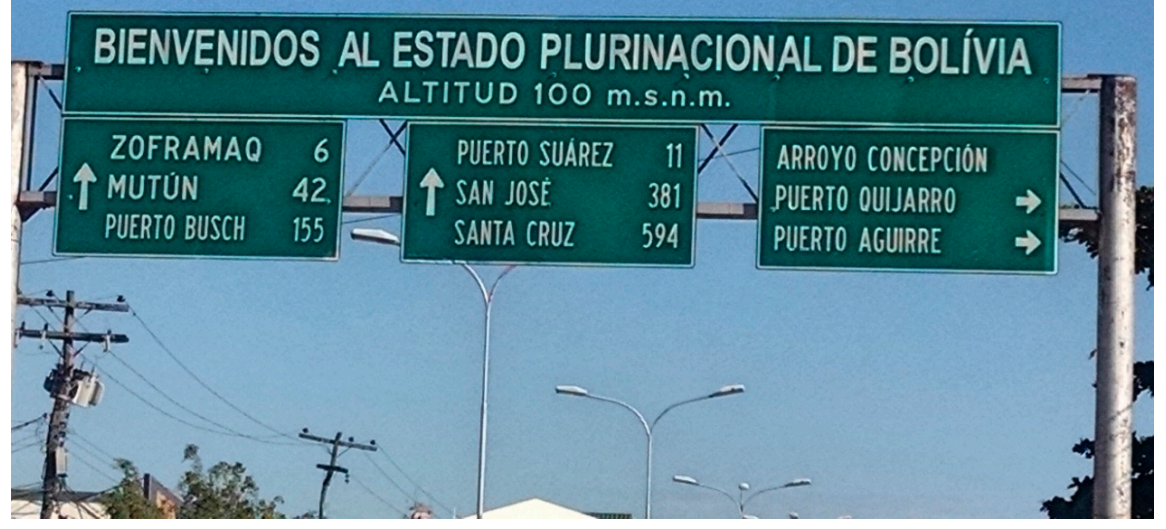

Foto 1 - Portal de entrada na cidade de Puerto Quijarro, extremo-leste do Departamento de Santa Cruz, Bolívia, junto à fronteira com o Brasil.

Foto: Aldomar A. Rückert, 2015. 
O Corredor Bioceânico Central Porto Alegre (BR) - Coquimbo $(\mathrm{CH})$, (ver mapas 1 e 2) configura uma linha quase reta de $2.472 \mathrm{~km}$ que atravessa a Diagonal Desértica sul-americana, na região geográfica de Cuyo (que significa “país de areia”) e Sierras Pampeanas, na Pré-Cordilheira dos Andes. Nesta região estão situados a Ruta Nacional $150^{8}$ (ver foto 2) e os parques naturais de Ischigualasto (Vale de La Luna) e Talampaya a $158 \mathrm{~km}$ das cidades de La Rioja, $330 \mathrm{~km}$ de San Juan e a $470 \mathrm{~km}$ de Mendoza.

A Ruta 150 é uma via cênica que cruza a Serra de Vale Fértil, um subsistema das Sierras Pampeanas, com seis túneis e com uma engenharia complexa. Por um lado, a via permitirá vincular os núcleos produtivos das regiões argentinas do Pampa Úmido, o Litoral e o Norte Argentino e, futuramente, com o porto de águas profundas de Coquimbo, na IV Região do Chile, possibilitando um novo caminho para o intercâmbio comercial com os países da bacia Ásia-Pacífico (Ruta Nacional 150), além de articular-se com a Ruta Nacional 40, rodovia estrutural que percorre a Argentina de sul a norte, da extrema Patagônia à fronteira com a Bolívia.

Encontros entre comitivas de empresários chilenos e do Brasil têm se repetido para tratar dos interesses do empresariado de ambos os países em baratear custos de logística nas exportações para a Ásia e no comércio entre os dois países. (Sistema Fiergs 2015). As ações de associações de empresários brasileiros, argentinos e chilenos no que diz respeito a demandar as obras do Corredor Bioceânico Central Porto Alegre (BR) - Coquimbo $(\mathrm{CH})$ demonstram com clareza a participação civil de capitais privados e seus interesses neste novo caminho terrestre. Além disso, suas ações de demandas junto aos órgãos dos governos nacionais demonstram, com grande clareza, a multidimensionalidade de atores e suas diversas escalas de poder. Um verdadeiro "entrelaçamento" de atores e ações em três países revela o adensamento não apenas da indústria, comércio e serviços na região núcleo do Mercosul, mas também a capacidade de mobilização política de atores privados em diversas escalas de poder.

Com a construção da obra monumental Túnel Água Negra9 ${ }^{9}$ deverá se concluir o novo Corredor Bioceânico Porto Alegre (RS, Brasil) - Coquimbo (Chile), que interligará as regiões agrícolas e industriais do sudeste e do sul do Brasil com o Oceano Pacífico, encurtando caminhos para a exportação de soja, carne e ferro, por exemplo, para o mercado asiático e para a entrada de automóveis e produtos eletrônicos provenientes da Ásia. A médio e longo prazos pode-se prever que venha a ocorrer uma relativa abertura da região periférica de Cuyo e Sierras Pampeanas e a ligação mais intensa dos parques naturais aos fluxos comerciais e turísticos argentinos, brasileiros e chilenos. 


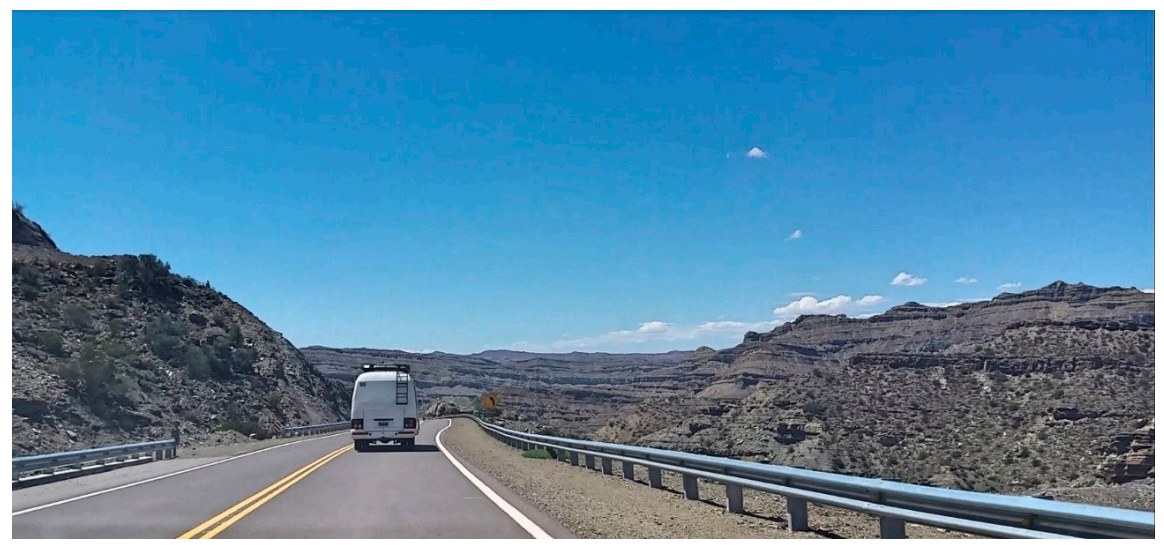

Foto 2 - Trecho da Ruta Nacional 150, entre o Parque Nacional Talampaya (Província de La Rioja, ARG) e San José de Jachal (Província de San Juan, ARG).

Foto: Aldomar A. Rückert, 2017.

\section{O Eixo das Guianas na Região das Guianas}

A Região das Guianas corresponde a uma região periférica na Amazônia. Parte desse isolamento se explica pela estratégia do governo brasileiro de manter a região Norte do país relativamente desprovida de conexões terrestres. Porto $(2010,139)$ entende que a Amazônia segue sendo tratada como periférica pelo governo federal do Brasil, bem como pelas elites locais. $\mathrm{Na}$ Região das Guianas, processos de transfronteirização encontram-se em estágios embrionários, tendo em vista os vastos espaços ocupados por florestas, as grandes distâncias entre as cidades e povoados e o pequeno volume de circulação de mercadorias e pessoas pelo interior amazônico, restritos quase que ao movimento de mineradores, via de regra ilegais. Além destes aspectos, deve-se ressaltar, a região das Guianas pode revelar-se um laboratório de observações de ações de diversos atores em múltiplas escalas, como já demonstrado por Silva e Rückert (2009) e Silva (2014). A baixa densidade de organizações de atores civis, de forma diferente do centro-sul do Brasil e do Mercosul, faz com que os atores principais sejam os governos nacionais e seus exércitos, os governos do Estado do Amapá e da coletividade territorial da Guiana Francesa e, com menor importância, os governos locais das cidades do Oiapoque e de Saint-George na Guiana Francesa. Isto é, predominam as relações entre Estados nacionais e seus níveis de governo subnacionais.

Até o presente, apenas três rodovias brasileiras (BR-156, BR-174 e $\mathrm{BR}-401$ ) conectam a área correspondente à calha norte do rio Amazonas 
aos países vizinhos (ver mapa 3). A ausência de infraestruturas de transporte terrestre e a presença de grandes áreas de preservação (como a savana de Rupununi, uma planície de savana na Guiana, na região de Upper Takutu-Upper Essequibo, parques nacionais como o do Monte Roraima, terras indígenas como a Raposa Serra do Sol, etc.) são fatores que dificultam enormemente o trânsito de pessoas e mercadorias na região, mas que, ao mesmo tempo, servem de defesa contra uma eventual invasão por parte de um país inimigo. De acordo com o Programa de Desenvolvimento da Faixa de Fronteira, “[ [...] o reconhecimento das terras indígenas e a criação de unidades de conservação atuam no sentido de estabilizar o povoamento e dificultar a entrada de frentes pioneiras internas e externas" (Brasil 2009, 35).

No que tange à Guiana Francesa, Silva (2014) destaca que, apesar de se tratar de um Departamento-região de ultramar francês, em função de seu isolamento, a concentração demográfica (a população ocupa essencialmente o litoral) e da forte dependência em relação à França metropolitana, o território apresenta problemas e deficiências semelhantes aos dos países sul-americanos. Apesar dos recursos obtidos em virtude do Centro Espacial de Korou (da Agência Espacial Europeia), as taxas de desemprego são altas e é grande o peso do setor primário na economia (pesca e madeira).

Apesar do contexto geopolítico pouco favorável e da pequena importância econômica da região (que poderia ser completamente alterada em caso de um aumento significativo dos preços do petróleo no mercado internacional), há projetos do Cosiplan para a Região das Guianas por serem implementados que, na quase totalidade, contemplam obras do setor de transportes, merecendo destaque um conjunto de pontes e rodovias que, juntos, formariam a rodovia Transguianense. A inauguração da ponte sobre o rio Takutu (no limite internacional entre Bonfim, Roraima-Brasil e Lethem, República Cooperativa da Guiana), em 2009, e o atraso de mais de 6 anos na abertura extraoficial da ponte internacional Amapá-Guiana Francesa - concluída em 2011 e inaugurada em 2017 - são alguns exemplos de obras concluídas, mas que não alteram significativamente o cenário macrorregional de infraestruturas precárias. 


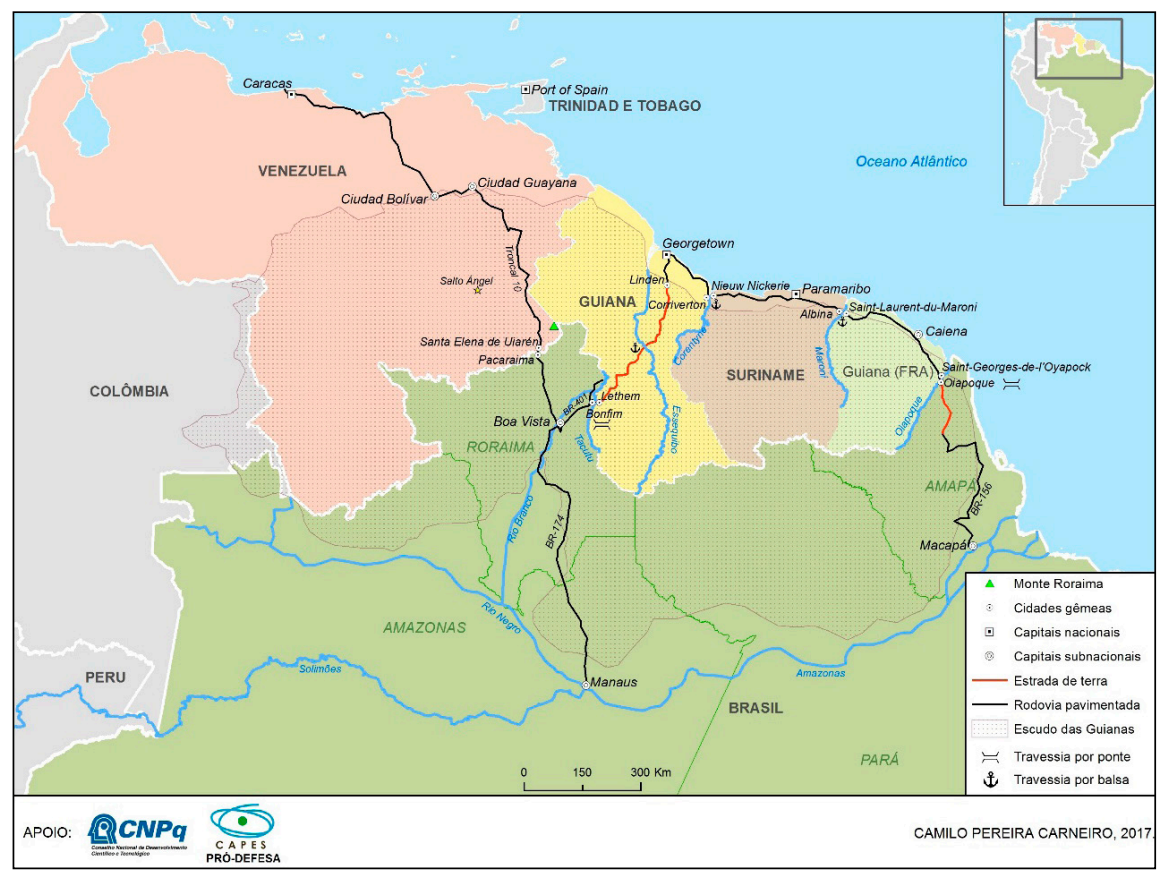

Mapa 3 - Eixo do Escudo das Guianas no Brasil, Guiana Francesa, Suriname, Guiana e Venezuela.

A rodovia BR-156, no Estado do Amapá, obra federal do Brasil mais antiga ainda em andamento, teve início na década de 1940, e que em 2017 ainda possuía um trecho de pouco mais de $100 \mathrm{~km}$ sem pavimentação. Desde 2000, as obras da IIRSA-Cosiplan vinham sendo executadas pelas grandes empreiteiras brasileiras, que contavam com o financiamento do BNDES. A partir de 2014, essas empreiteiras foram impactadas pela Operação Lava Jato, da Polícia Federal do Brasil, que revelou esquemas de corrupção em licitações e de desvio de verbas públicas dos quais faziam parte as maiores empreiteiras do Brasil.

Uma vez retomados os investimentos nas obras da IIRSA-Cosiplan numa conjuntura mais favorável para a Região das Guianas, a região poderia sentir os impactos da conexão entre espaços com baixas densidades de capital, baixa densidade populacional e de meios técnicos, além da alteração na fluidez da circulação. No trajeto entre Georgetown, a capital da República Cooperativa da Guiana, e a cidade de Lethem, na fronteira com o Brasil, por exemplo, grande parte da rodovia (aproximadamente $300 \mathrm{~km}$ ) não é asfaltada (ver foto 3). ${ }^{10}$ Além disso, a viagem é dificultada 
pelos poucos horários de funcionamento da balsa que faz a travessia do rio Essequibo, o que ocorre apenas duas vezes ao dia (a cada 12 horas). O percurso, que no período de poucas chuvas dura em média 24 horas, em função das condições da estrada, é realizado por meio de vans, que transportam em seu interior, junto com os passageiros, mercadorias de todo tipo (material de construção, alimentos e até galões de gasolina), o que torna a viagem muito perigosa, desconfortável e cansativa.

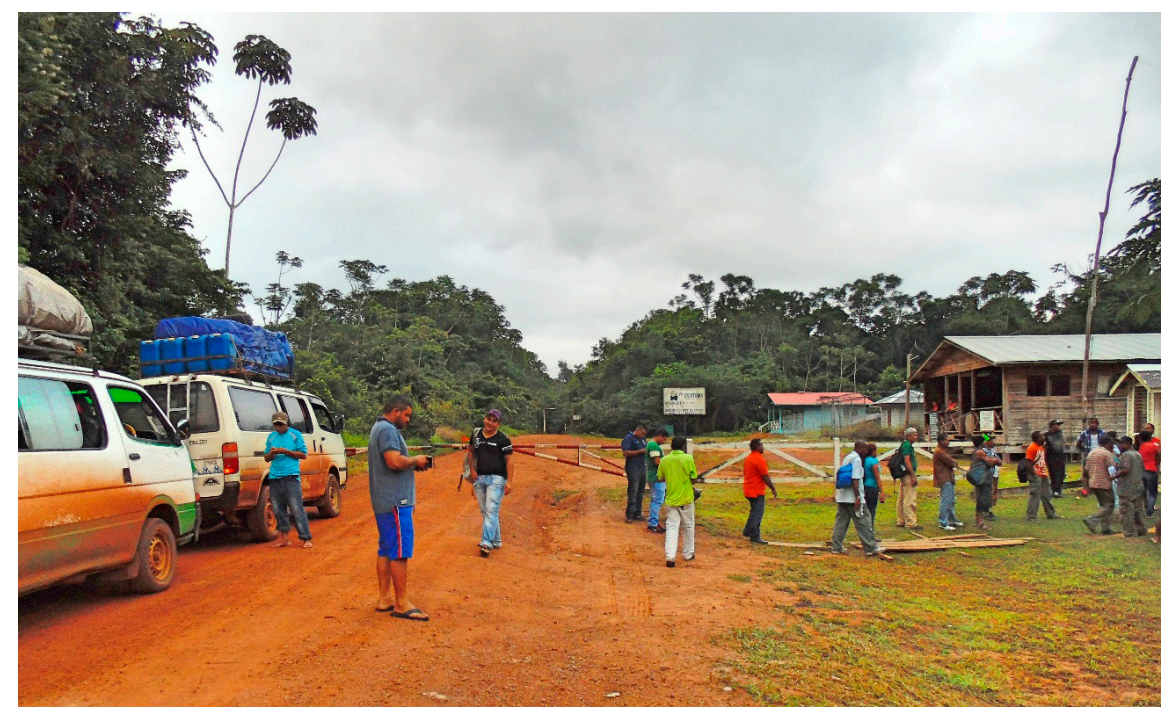

Foto 3 - Barreira de fiscalização da polícia guianense na rodovia Georgetown - Lethem (Guiana) - Bonfim (Roraima, Brasil).

Foto: Camilo Pereira Carneiro, 2013.

Além das obras futuras previstas, cabe destacar a necessidade da homogeneização das diferentes legislações entre os países. A União Europeia, por exemplo, não permite a circulação de veículos que poluam mais do que o estabelecido pelas normas do Regulamento (CE) $n^{\circ} 715 / 2007 .{ }^{11}$ Ainda que a questão das divergências entre as legislações venha a ser dirimida, é importante ressaltar que uma eventual retomada dos projetos de infraestrutura na Região das Guianas poderia gerar impactos positivos, mas também negativos. De um lado, as obras de conexão viária serviriam como fator impulsionador do turismo ecológico nos parques nacionais da Região das Guianas, que têm no Monte Roraima (tríplice fronteira BrasilVenezuela-Guiana) e no Salto Ángel (Venezuela) seus grandes atrativos. 
Contudo, a facilidade de movimentação também poderia trazer impactos negativos ao potencializar atividades criminosas, propiciando a entrada de garimpeiros clandestinos e o comércio e transporte de drogas na região.

\section{QUAIS SÃO OS RUMOS ATUAIS DA INTEGRAÇÃO SUL-AMERICANA?}

Neste último tópico apresentam-se considerações sobre os rumos atuais da integração sul-americana e das infraestruturas de conexão, cenário onde há, atualmente, uma verdadeira ausência de continuidade do ideário da América do Sul como uma região geopolítica. Pode-se mesmo afirmar que ela é pouco visível na Unasul e nas tendências políticas de governos que têm feito opções por medidas ortodoxas de contenção de investimentos e voltadas para o mercado por vias privatizantes.

Vários projetos de integração política, econômica e de infraestruturas de articulação viária e energética na América do Sul encontram-se fortemente condicionados à crise mundial pós-2008, mais notadamente a partir dos anos 2011-2012 e à própria ausência de uma política externa do Brasil para a região no governo Michel Temer. Os anos dourados das economias exportadoras e dos avanços da integração sul-americana chegaram ao fim com o ambiente recessivo da economia mundial; o golpe de Estado no Paraguai em 2012, com a deposição de Fernando Lugo, o que já indicou o início do retrocesso dos governos progressistas e da integração da região; a morte de Hugo Chávez, em 2013; a crise política em que se encontra a Venezuela e sua atual suspensão do Mercosul; a retomada de programas neoliberais por governos que se sucedem pós-2015 na Argentina, com a eleição de Maurício Macri; e a deposição, por meio de golpe parlamentar, de Dilma Rousseff no Brasil, principalmente.

Estudo recente da organização Global South demonstra que a economia mundial ainda não se recuperou dos efeitos da crise financeira que iniciou há quase uma década atrás (Akyüz, Yu III 2017). A crise moveu-se numa terceira onda para várias economias emergentes após haver-se movido dos Estados Unidos para a Europa. As principais economias emergentes que eram esperadas tornar-se locomotivas globais (BRICS: Brasil, Rússia, Índia, China e África do Sul) alguns anos atrás, agora são vistas como parte do problema, gerando impulsos deflacionários para a economia mundial. Como afirma Conde (2017), China e Índia enfrentam dificuldades concernentes a suas taxas de crescimento e o Brasil está em colapso, onde agitações violentas têm acontecido, com a população exigindo mudanças dos rumos econômicos e políticos.

O governo de Michel Temer, então vice-presidente de Dilma Rousseff (2011-2016), e que a sucedeu em seu segundo governo a partir de maio 
de 2016, por meio de um golpe parlamentar, mudou as diretrizes políticas eleitas democraticamente em 2014, de linhas desenvolvimentistas com ampla inserção social e redistribuição de renda, optou-se pela associação com os grandes bancos e indústrias, promovendo programas neoliberais e privatistas com reformas econômicas recessivas. O economista José Serra, de orientação político-ideológica neoliberal, ao assumir como Ministro das Relações Exteriores em 2016 (demitiu-se em 2017) mudou a agenda diplomática do Brasil para a América do Sul. Além de severo crítico dos governos populares no país e nos países vizinhos (mudando o princípio da não intervenção nos assuntos internos de outros Estados), as ações ministeriais voltaram-se contra o projeto do Brasil aspirar a um assento permanente no Conselho de Segurança da ONU; a própria participação brasileira e da Venezuela no Mercosul, tendo agido para suspender o país por tempo indeterminado, alegando descumprimento de obrigações de tratados e normas técnicas (Spektor 2017). Além disso, mudou-se a prioridade da política brasileira de diversificar as relações do Brasil com todos os Estados e, finalmente, com a tentativa de alinhar o país com a política externa norte-americana em todos os temas, sem colocar acima de tudo os interesses brasileiros (Lírio 2017).

$\mathrm{O}$ atual governo brasileiro não possui mais um projeto de desenvolvimento para a América do Sul e tampouco uma política externa ativa enquanto que a China avança com investimentos sobre a região. Houve ausência brasileira na mediação do processo de paz da Colômbia, enquanto que Suriname, Guiana, Bolívia, Equador e Venezuela (quase a metade da América do Sul) são, hoje, estranhos à política externa do país. A recente decisão, no mês de abril de 2018, do Brasil e de mais cinco países (Argentina, Paraguai, Colômbia, Chile e Peru) de suspender sua participação na Unasul (Istoé 2018) corrobora a inexistência nestes países de uma política externa para a América do Sul. Os seis países emitiram comunicado conjunto alegando que não estavam mais dadas as condições para adotar decisões no âmbito da Unasul, visto que a organização se encontra sem um secretário geral desde janeiro de 2017, enquanto que o chefe de fato, o colombiano Yuri Chillán demitiu-se em 31 de julho de 2018. No entanto, Macri, na Argentina, já havia planejado uma mudança radical na política exterior do país desde que assumira em dezembro de 2015, focando o Mercosul como prioridade. As divergências ideológicas dos governos atuais de Brasil e Argentina, principalmente, com o governo de Maduro, são a razão do afastamento destes países da organização (Dapelo 2018).

Enquanto se aprofundam as divergências dos governos em torno da Unasul, os EUA avançam gradualmente sua influência sobre o Paraguai, Suriname, Colômbia e Argentina com cooperações ou a presença de bases 
militares, tornando a região uma arena de disputas comerciais e políticas com a China, enquanto que a Aliança do Pacífico - Colômbia, Peru, Chile e México - se fortalece (Kalout 2017). Além disso, estes países deram os primeiros passos rumo à criação de um fundo comum para financiamento de infraestrutura, além de passar a contar com Canadá, Austrália, Nova Zelândia e Cingapura em acordos que contemplam a livre circulação de bens e serviços, além de facilidades para a mobilidade dos cidadãos (Manetto 2017).

Neste contex to de incertezas sobre os rumos políticos da Unasul, vozes de oposição a criticam, afirmando que a organização perdeu sua razão de ser, devendo-se acabar com ela de uma forma ordenada "o mais rapidamente possível” (Montoya 2017). A atuação anti-hegemônica aos interesses dos EUA dos governos de esquerda na região nos anos 2000, além de projetos extra-regionais como os BRICS, enfrenta uma contrarreação com a definição do Atlântico Sul como espaço estratégico de relevância crescente para os EUA no contexto de iniciativas para conter o poder sino-indiano-brasileiro na América do Sul e África (Pecequillo 2016).

Analisando-se os resultados obtidos pela então denominada IIRSA ao final dos anos 2000, Padula (2014) afirma que as ações governamentais haviam se concentrado em pequenos projetos de transporte e deixando de lado a possibilidade de levar à frente projetos estruturados, tendo o próprio BID emitido parecer neste sentido. Afirma o Relatório do BID, reconhecendo o surgimento do empoderamento dos países sul-americanos em meados dos anos 2000, que os esforços realizados pelo Cosiplan não haviam sido suficientes para melhorar os índices de qualidade e disponibilidade de infraestrutura e nem para conseguir uma melhora na competitividade da região sul-americana. "Por um lado, a posição da região na ordem mundial de qualidade da infraestrutura tem piorado, e por outro, a lacuna entre o volume de comércio externo e o stock de infraestruturas de integração tem-se ampliado" (Banco 2008). No mesmo sentido de críticas ao Cosiplan, estudo da Confederação Nacional da Indústria - CNI - aponta que a queda da participação da região no comércio exterior brasileiro nos dois últimos decênios deve-se, entre outros fatores, à má qualidade da infraestrutura (Confederação 2015).

Em que pesem as críticas aos projetos do Cosiplan, há estudos que apontam crescimento do comércio internacional após 2011, com a conclusão de rodovias internacionais como a Rodovia do Pacífico, também conhecida como Rodovia Interoceânica, estrada binacional Brasil-Peru, que liga o noroeste do Brasil ao litoral sul do Peru, através do estado brasileiro do Acre. Embora o comércio entre os dois países continue mais expressivo pelos transportes aéreo e marítimo, houve aumento de $3 \%$ nas exporta- 
ções brasileiras e 5\% nas peruanas somente através deste modal rodoviário (Interoceânica 2017).

As críticas aos governos que criaram a Unasul, as instabilidades políticas na região e as denúncias de corrupção de ex-autoridades governamentais trazem novos complicadores para o futuro da organização, ao menos no que diz respeito à participação de empreiteiras brasileiras em obras de infraestrutura promovidas pelo Cosiplan. As denúncias e processos têm-se estendido a vários países, dentre eles Equador, Peru, Argentina, México, República Dominicana, Panamá, Colômbia e Venezuela (Barrocal 2017, Benites 2017). No Peru, o fim da participação da empreiteira brasileira Odebrecht em dois projetos de infraestrutura - a Rodovia Interoceânica que liga o Brasil ao Peru e a represa Chavinomochia III - e as acusações contra ex-presidentes e ex-ministros levaram o ex-presidente Kuczynski a afirmar que não há como negar que o caso Odebrecht "é um freio para a economia” (Fowks 2017). A recente prisão do ex-presidente Ollanta Humala, acusado de lavagem de dinheiro em doações feitas pelo grupo brasileiro Odebrecht em suas campanhas presidenciais de 2006 e 2011 (Humala exerceu o mandato entre julho de 2011 e julho de 2016) (Tola 2017) confirma o cenário de complicações políticas e jurídicas para os projetos de integração da infraestrutura sul-americana, ao menos no que diz respeito à participação de empreiteiras brasileiras em projetos da carteira da Cosiplan. Já Kuczynski renunciou ao governo do Peru no fim do mês de março de 2018 para não ser cassado pelo Congresso peruano devido aos envolvimentos em escândalos de corrupção com a construtora brasileira Odebrecht.

Em consonância com a retomada do alinhamento do Brasil com a política externa norte-americana, o atual governo brasileiro está novamente em negociação, após Lula cancelar a proposta do governo anterior de Fernando H. Cardoso, para ceder o usufruto da base militar de Alcântara (no estado do Maranhão, na região Nordeste do Brasil) para o governo norte-americano lançar satélites, com riscos que a área venha a ser utilizada para o lançamento de ogivas nucleares. Além disto, o governo brasileiro firmou, em março de 2017, acordo de parceria tecnológica com os EUA para incentivar a indústria nacional de defesa. $\mathrm{O}$ acordo, diz a nota da agência de notícias financeiras Bloomberg, é o "último sinal duma mudança na política externa” na maior economia da América Latina após o fim de mais de uma década de governos de esquerda com o impeachment da Presidente Dilma Rousseff (Adghirni 2017). Em novembro de 2017 ocorreu a Operação Amazon Log Brasil e Estados Unidos na tríplice fronteira entre Peru, Brasil e Colômbia. O exército dos EUA teria participado do exercício militar multinacional de simulação de ações de ajuda huma- 
nitária, segundo o general Guilherme Cals Theophilo Gaspar de Oliveira, comandante logístico do Exército brasileiro (Nascimento 2017). Em contraposição, a ala nacionalista do Exército brasileiro considerou a presença dos norte-americanos na região estratégica da tríplice fronteira um crime de lesa-pátria (Melo 2017). Além disto, a recente visita do vice-presidente norte-americano Mike Pence nos dias 26 e 27 de junho a Brasília e Manaus com preocupações aparentemente humanitárias com a crise dos refugiados venezuelanos indica claramente a pressão do governo de Donald Trump para que o governo brasileiro aumente o isolamento da Venezuela na América do Sul (Sampaio 2018).

Neste cenário de crise e incertezas na América do Sul é sintomática a recente publicação do Banco Mundial anunciando a renovação do regionalismo aberto, opção neoliberal dos anos 90, com propostas para toda a América Latina, enfatizando que os ganhos potenciais de toda a região podem ser atingidos combinando-se reformas estruturais e futura liberalização do comércio com o resto do mundo (Bown et al. 2017). Diz o estudo do Banco que ainda há espaço para mais acordos preferenciais, especialmente entre América do Sul e Central e a América do Norte.

Evidencia-se que o Banco Mundial volta a ocupar espaço como conselheiro de governos que se sucedem aos progressistas dos anos $2000 \mathrm{com}$ opções preferenciais por privatizações, medidas econômicas ortodoxas e alianças com o poder hegemônico norte-americano. $\mathrm{O}$ banco volta a sugerir medidas já experimentadas na América Latina na década de 1990, que redundaram em aprofundamento das crises econômicas e recessões com altíssimos custos sociais. A América do Sul está frente a uma encruzilhada com prenúncios de graves retrocessos políticos que tenderão a perpetuar seus problemas crônicos.

\section{CONCLUSÃO}

Abordar políticas territoriais em processos de integração na escala sul-americana constitui-se num grande desafio para a Geografia Política e a Geopolítica. A região-continente ou região geopolítica América do Sul apresenta grandes assimetrias internas, o que dificulta sobremaneira as observações, a análise territorial e as previsões de possíveis transformações. Possíveis relações entre políticas públicas e suas repercussões territoriais configuram uma questão de investigação ainda relativamente recente no cenário sul-americano, muito embora haja vários esforços para se compreender os processos de integração das infraestruturas da IIRSA-Cosiplan.

A começar pela dificuldade da ausência de uniformidade de dados secundários nacionais, a análise territorial encontra ainda pouco respaldo na 
literatura especializada, salvo os estudos com abordagens regionais focados em escalas subnacionais e/ou, eventualmente, transfronteiriças. O desafio da análise territorial em escala supranacional sul-americana implica numa visão de conjunto da região-continente, com a utilização de dados nacionais (ainda não uniformes entre os Estados) e de cartografias temáticas que possam demonstrar tanto algumas homogeneidades e heterogeneidades como as profundas assimetrias e fraturas territoriais. A abordagem multiescalar das ações de múltiplos atores, no entanto, tem se mostrado um campo fértil para a interpretação de transformações territoriais que ultrapassem as fronteiras nacionais ainda que este tipo de investigação se encontre de forma embrionária.

A perspectiva dos regionalismos recebeu na América do Sul nos anos 2000, inegavelmente, um conjunto de políticas progressistas que ampliaram e aprofundaram os objetivos do velho regionalismo e do regionalismo aberto. O projeto da América do Sul como uma região geopolítica na escala macro da Unasul introduziu, provavelmente, após o fim da Guerra Fria, pela primeira vez no subcontinente, não apenas o resgate dos ideais integracionistas do século XIX, mas também uma verdadeira inovação político-territorial com características institucionais direcionadas ao exercício da contra-hegemonia norte-americana e à coesão política interna.

A transformação da IIRSA - um instrumento direcionado à integração física de mercados, direcionado por visões politicamente conservadoras atreladas ao predomínio do Banco Interamericano de Desenvolvimento (BID) - em Cosiplan apontou, de forma inovadora, para políticas territoriais em escala sul-americana direcionadas não apenas aos elos de ligação física entre os Estados nacionais, mas também a entendimentos de que investimentos provindos de diversas escalas de poder e gestão poderiam mudar os usos políticos e econômicos do território sul-americano, tanto de regiões desenvolvidas quanto das periféricas e subdesenvolvidas. Pretendeu-se que o planejamento do Cosiplan pudesse, de alguma forma, contribuir para a diminuição de assimetrias e fraturas territoriais. A perspectiva das assimetrias remeteu à indagação sobre em que medida ocorrem transformações em regiões periféricas - o que ainda é questão em aberto à investigação.

O exame dos três casos empíricos revelou-se fortemente elucidativo do que pode e o que não pode ser uma região periférica no interior da América do Sul. As observações de campo em duas regiões, em Cuyo, Argentina e na Região das Guianas, possibilitou percorrer grandes distâncias rodoviárias para descobrir conteúdos que são pouco conhecidos, mesmo por geógrafos, como é o caso dos parques naturais de Talampaya e Ischigualasto, ao lado da Ruta Nacional 150 na região pé-andina, bem como no interior amazônico da Guiana Francesa, Suriname e República Cooperativa da Guiana. 
Não foi intenção do autor, neste artigo, apontar uma metodologia de identificação de regiões periféricas na América do Sul. Esta, com certeza, se tornará uma outra demanda para a análise territorial em breve. Entretanto, a partir de projetos de infraestrutura foi possível aproximar-se de algumas regiões definidas geograficamente com é o caso de Cuyo, na Argentina. O caso boliviano, por sua vez, é importante não apenas por evidenciar as contradições e discrepâncias do processo de integração sul-americano, mas também por evidenciar que atores territoriais locais e regionais deveriam fazer parte da agenda da integração. Entretanto, estes atores, como o estudo de caso evidenciou, vêm sendo desprezados por atores hegemônicos que representam interesses e poderes nacionais e/ou supranacionais.

Já o estudo de caso na Região das Guianas, reconhecidamente uma macrorregião extensa e complexa, só muito recentemente abordada na literatura geográfica brasileira, mostrou o quanto regiões periféricas podem estar em descompasso com a agenda supranacional da IIRSA-Cosiplan. Enquanto o Eixo Mercosul-Chile, por meio do estudo de caso da Corredor Bioceânico Porto Alegre - Coquimbo e da Ruta Nacional 150, exemplificou o arco geoeconômico entre o sudeste e o sul do Brasil, o centro da Argentina e os portos do Pacífico no Chile, com importantes processos de mudança de usos políticos e econômicos do território e de processos de transfronteirização, o Eixo do Escudo das Guianas demonstra o quanto o isolamento geográfico - pelas distâncias e pela presença da Floresta Amazônica - ainda é imperativo e determinante em processos de decisão governamentais e supranacionais. Talvez não seja demasiado concluir que algumas repercussões territoriais da IIRSA-Cosiplan na Região das Guianas sejam praticamente nulas, resguardando-se, principalmente, duas pontes internacionais concluídas (pontes sobre o rio Oiapoque entre o estado do Amapá-BR e a Guiana Francesa, e sobre o rio Takutu, entre o estado de Roraima-BR e a República Cooperativa da Guiana) e instalação de linhas de fibra ótica entre Caracas-Venezuela e o norte do Brasil.

A rigor, poder-se-ia afirmar que há mais espaços opacos e regiões periféricas na América do Sul do que regiões que tenham recebido de bancos e governos nacionais estímulos para alterar os perfis geoeconômicos do vasto interior empobrecido. A tendência atual é destes governos voltarem a seguir os preceitos do Consenso de Washington, do Banco Interamericano de Desenvolvimento - BID - e do Banco Mundial com programas neoliberais e privatistas. O Brasil, país que vinha liderando o processo integracionista na região, atualmente ausenta-se da política externa e da Unasul. Além disso, as denúncias de corrupção generalizada em obras de infraestruturas de conexão praticamente têm inviabilizado muitos projetos que 
vinham sendo financiados pelo BNDES, com a exportação de serviços de empresas brasileiras.

Não bastasse o retorno ao neoliberalismo de vários governos da região, a preconização da renovação do regionalismo aberto pelo Banco Mundial é um anúncio do rápido retorno da América do Sul à condição de satélite na órbita de influência norte-americana. Às regiões periféricas poderá restar o destino da continuidade do estado de isolamento e de miséria de uma população que tradicionalmente são os deserdados da terra sul-americana.

A fluidez territorial almejada deverá, em grande medida, talvez ainda ser um dos principais desafios, visto que as fraturas entre os Estados-nação, principalmente entre o Brasil e seus vizinhos, continuarão existindo, visto se tratar de situações crônicas seculares. A infraestrutura estratégica vertida para o exterior deverá continuar a constar na pauta da integração de mercados para aproximar a região-continente dos mercados da Bacia do Pacífico. Já a macrorregião transfronteiriça da Bacia do Prata, por sua vez, continuará a ser a mais importante da América do Sul, visto o grande número de cidades gêmeas e de permeabilidades entre Brasil, Uruguai, Paraguai e Argentina, enquanto regiões como a Região das Guianas continuarão como uma espécie de utopia da integração sul-americana, permanecendo mais próxima da região do Caribe não apenas pelo fator distância mas também por sua identidade territorial. Somente a conjuntura econômica internacional dirá se grandes empresas, dentre elas as chinesas, farão investimentos como o da construção do túnel de Água Negra, nos Andes, provavelmente a obra mais importante da Agenda de Projetos Prioritários de Integração do Cosiplan.

\section{REFERÊNCIAS}

ABTI. Associação Brasileira de Transportadores Internacionais. http://www. abti.com.br/. Acesso em: agosto de 2017.

Adghirni, Samy. 2017. U.S. Military Agreement With Brazil to Prompt Joint Defense Deal. Disponível em: <https://www.bloomberg.com/news/articles/201703-23/u-s-military-agreement-with-brazil-to-prompt-joint-defense-deal $>$. Acesso em: 23 mar. 2017.

Akyüz, Yllmaz; Yu III, Vicente P. 2017. The financial crisis and the global south: impact and prospect. Genèva: South Centre Research PapeR76. Disponível em: $<$ https://www.southcentre.int/wp-content/uploads/2017/05/RP76_The-FinancialCrisis-and-the-Global-South-Impact-and-Prospects_EN.pdf $>$. Acesso em: 15 jul. 2017. 
ALADI - Associação Latino-americana de Integração. Sistema de informação de Comércio Exterior - Estatísticas por item tarifário de um país. Disponível em: <http://consultawebv2.aladi.org/sicoexV2/jsf/comercio_exterior_item_ arancelario.seam>. Acesso em: fev 2017.

Ariñez, Rubén. 2015. Evo anuncia que la carretera que atraviesa el TIPNIS "se realiza”. La Razon Nacional. 05 jun. 2015. Disponível em: <http://www.la-razon. com/nacional/Evo-carretera-atraviesa-TIPNIS-realiza_o_2283971614.html>. Acesso em: 15 mar. 2016.

Banco Inter-Americano de Desarrollo. 2008. Evaluación de la Acción del BID en la Iniciativa para la Integración de la Infraestructura Regional Suramericana (IIRSA). Washington, D.C., Abril de 2008. P. V. Disponível em: <http://services.iadb.org/ wmsfiles/products/Publications/1524534.pdf > . Acesso em: 12 abr. 2017.

Barrocal, André. 2017. Delação da Odebrecht nos EUA sacode a América Latina. Carta Capital. Disponível em: <https://www.cartacapital.com.br/internacional/ delacao-da-odebrecht-nos-eua-sacode-a-america-latina>. Acesso em: 02 jul. 2017.

Benites, Afonso. 2017. Brasil começa a enviar delação da Odebrecht a 8 países da região. El País. Disponível em: < https://brasil.elpais.com/brasil/2017/06/02/ politica/1496438612_350750.html>. Acesso em: 05 jul. 2017.

Bown, Chad P. et alii. 2017. Better Neighbors. Toward a Renewal of Economic Integration in Latin America. Washington, World Bank Group. Disponível em: $<$ https://openknowledge.worldbank.org/handle/10986/25736>. Acesso em: 30 jul. 2017.

Brasil e mais cinco países suspendem participação na Unasul. 2018. Istoé. 22 abr. 2018. Disponível em: <https://istoe.com.br/brasil-e-mais-cinco-paises-suspendem-participacao-na-unasul/>. Acesso em: 23 abr. 2018.

Brasil. 2009. Programa de Promoção do Desenvolvimento da Faixa de Fronteira $P D F F$. Brasília: Ministério da Integração Nacional.

Carwil B-J. 2015. Bolivian-Venezuelan Military construction team begins work on TIPNIS highway. Carwil without Borders. Disponível em: <https://woborders.blog/2015/06/29/bolivian-venezuelan-military-construction-team-beginswork-on-Tipnis-highway/>. Acesso em: 16 mar. 2017.

Chabrol, Denis. 2018. Construction of Linden-Lethem road to begin this year. Demerarawawes. 12 july 2018. Disponível em: <http://demerarawaves. com/2018/07/12/construction-of-linden-lethem-road-to-begin-this-year/>. Acesso em: 30 ago. 2018. 
Conde, Philippe. 2017. Les BIC : entre émergence et crise de croissance. Diploweb. 28 janvier 2017. Disponível em: <http://www.diploweb.com/Les-BIC-entreemergence-et-crise.html>. Acesso em: 02 jul. 2017.

Conectas. Direitos Humanos. 2015. Denúncia da Sociedade Civil ao BNDES por sua participação no Projeto de Rodovia Villa Tunari-San Ignacio de Moxos (Bolívia). São Paulo - La Paz - Londres, 20 out. 2015. Disponível em: <http://www.conectas.org/arquivos/editor/files/Conectas_GW_Cedla\%20-\%20Denuncia\%20 Ouvidoria\%20BNDES\%20-\%20Villa\%20Tunari-\%20San\%20Ignacio\%20 Moxos_20_10_2015.pdf>. Acesso em: fev. 2017.

Confederação Nacional da Indústria - CNI. 2015. Desafios para a integração logística na América do Sul. Brasília: Confederação Nacional da Indústria / Armando Castelar, 2015. Disponível em: <http://static-cms-si.s3.amazonaws.com/legacy/app/conteudo_18/2016/03/02/10642/0203-EstudoDesafiosparaaIntegraoLogsticadaAmericadoSul.pdf>. Acesso em: jun. 2017.

Cosiplan. 2016. Cartera 2016_web.pdf. Disponível em: <https://www.flipsnack. com/IIRSA/informe-de-la-cartera-de-proyectos-del-COSIPLAN-2016.html>. Acesso em: 30 ago. 2018

Cosiplan. API. 2016. Agenda de projetos prioritários de integração. Disponível em: $<$ http://www.iirsa.org/admin_iirsa_web/Uploads/Documents/api_agenda_de_ projetos_port.pdf>. Acesso em: 20 set. 2017.

Cosiplan. 2017. Agenda de Projectos Prioritarios de Integración 2017. Disponível em: $<$ https://www.flipsnack.com/IIRSA/informe-de-la-cartera-de-proyectos-delcosiplan-2017.html>. Acesso em: 30 ago. 2018.

Costa, Wanderley M. da. 2009. O Brasil e a América do sul: cenários geopolíticos e os desafios da integração. Confins [Online], 7. Posto online em 31 out. 2009. Disponível em: <http://confins.revues.org/6107>. Acesso em: 06 set. 2017.

Dapelo, Santiago. 2018. La Argentina y otros cinco países abandonan la Unasur. La Nacion. Disponível em: <https://www.lanacion.com.ar/2127623-la-argentina-y-otros-cinco-paises-abandonan-la-unasur2018>. Acesso em: 29 ago. 2018.

Dietz, Circe I. 2008. Cenários contemporâneos da Fronteira Brasil-Argentina: infraestruturas estratégicas e o papel dos atores no processo de cooperação/integração transfronteiriça. Porto Alegre: POSGEA/UFRGS. 238 f. (Dissertação de Mestrado).

Ebitan. Precalificación. Disponível em: <http://www.ebitan.org/index.php>. Acesso em: 30 ago. 2018. 
Fonseca, Bruno; Mota, Jessica. 2013. Pan-amazônia à Brasileira. Amazônia. 23/nov/2013. Disponível em: <http://amazonia.org.br/2013/11/panamaz\%C3\%B4nia-\%C3\%Ao-brasileira/>. Acesso em: 15 mar. 2017.

Fowks, Jacqueline. 2017. Kuczynski: "Não há como negar que o caso Odebrecht é um freio para a economia”. El País. Disponível em: <https://brasil.elpais.com/ brasil/2017/03/10/internacional/1489108861_588085.html>. Acesso em: 02 jul. 2017.

Index Mundi. Bolívia. Historical Data Graphs per Year Disponível em: <http:// www.indexmundi.com/g/g.aspx?v=21\&c=bl\&l=en>. Acesso em: 21 ago. 2017.

Interoceânica permitiu crescimento do comércio entre Brasil e Peru. 2017. Jornal da USP. Disponível em: <https://jornal.usp.br/ciencias/ciencias-humanas/ interoceanica-permitiu-crescimento-do-comercio-entre-brasil-e-peru/>. Acesso em: 03 ago. 2017.

Jimenez, Georgina. 2011. La carretera. ¿A quién beneficia. Villa Tunari-San Ignacio de Moxos. Petropress, 27 nov. 2011. Disponível em: <https://www.academia.edu/3292142/La_carretera_Villa_Tunari_San_Ignacio_de_Moxos_A_ qui\%C3\%A9n_beneficia.petropress>. Acesso em: 02 mar. 2017.

ISTOÉ. Brasil e mais cinco países suspendem participação na Unasul. 22/04/2018. Disponível em: <https://istoe.com.br/brasil-e-mais-cinco-paises-suspendemparticipacao-na-unasul/>. Acesso em: 13/03/2019.

Kalout, Hussein. 2017. Ausência de estratégia para América do Sul compromete ambições do Brasil. Disponível em: <http://www1.folha.uol.com.br/colunas/hussein-kalout/2017/01/1852198-brasil-precisa-reformular-uma-estrategia-para-aamerica-do-sul.shtml>. Acesso em: 13 fev. 2017.

Lírio, Sérgio. 2017. "A passagem de José Serra pelo Itamaraty foi desastrosa". Carta Capital. 17 mar. 2017. Disponível em: <https://www.cartacapital.com.br/ internacional/a-passagem-de-jose-serra-pelo-itamaraty-foi-desastrosa $>$. Acesso em: 02 mai. 2017.

Manetto, Francesco. 2017. Aliança do Pacífico incorpora mais quatro países. El País. Disponível em: <https://brasil.elpais.com/brasil/2017/07/01/internacional/1498863536_644235.html>. Acesso em: 30 jul. 2017.

Martinez, Paola. 2013. Bolivia frente a la IIRSA-Cosiplan? Entre el extractivismo y la integración? Buenos Aires: CLACSO. Disponível em: <http://biblioteca.clacso. edu.ar/clacso/becas/20131016053606/Informe.pdf>. Acesso em: mar. 2017. 
Melo, Liana. 2017. Militares americanos na Amazônia causam discórdia no Exército brasileiro. Projeto \#Colabora. 21 jul. 2017. Disponível em: <http:// projetocolabora.com.br/florestas/gringos-de-farda-na-amazonia-amazonlog/> . Acesso em: 30 jul. 2017.

Montoya, Rodrigo B. 2017. Darle sepultura a Unasur. El Colombiano. Disponível em: $\quad<$ http://www.elcolombiano.com/opinion/columnistas/darle-sepultura-aunasur-AL6728020>. Acesso em: 12 jul. 2017.

Nascimento, Luciano. 2017. EUA participam como observadores de exercício militar na Amazônia. EBC Agência Brasil. Disponível em: <http://agenciabrasil. ebc.com.br/geral/noticia/2017-11/eua-participam-como-observadores-de-exercicio-militar-na-amazonia>. Acesso em: 19 mar. 2018.

Padula, Raphael. 2014. Da IIRSA à Cosiplan da UNASUL: a integração de infraestrutura na América do Sul nos anos 2000 e suas perspectivas de mudança. In: NETO, Walter A. D. (org.). O Brasil e as novas dimensões da integração regional. Rio de Janeiro: IPEA, 291-351. Disponível em: <http://www.ipea.gov.br/agencia/ images/stories/PDFs/livros/livros/livro_brasil_novas_dimensoes.pdf > . Acesso em: fevereiro de 2017.

Pecequillo, Cristina S. 2016. O reposicionamento estratégico dos Estados Unidos na América do Sul. In: Passos, Rodrigo D. F.; Fuccille, Alexandre (orgs). Visões do Sul: crise e transformações do sistema internacional. Marília: Oficina Universitária; São Paulo: Cultura Acadêmica, 229-246. Disponível em: <https://www.marilia. unesp.br/Home/Publicacoes/visoes-do-sul_vol.1-ebook.pdf $>$. Acesso em: mar. 2017.

Pfrimer, Matheus H. 2011. Heartland Sul-americano? Dos discursos geopolíticos à territorialização de um novo triângulo estratégico boliviano. GEOUSP - Espaço e Tempo, São Paulo, no. 29: 131-144, 2011. Disponível em: <https://www.revistas. usp.br/geousp/article/view/74192>. Acesso em: out. 2016.

Pronunciamento Público de la Sub-Central de Mujeres Indigenas del Territorio Indigena Parque Nacional Isiboro Secure Tipnis. 2017. Sub central de pueblos indígenas. Trinidad, 04 mar. 2017. Disponível em: <https://pt.scribd.com/document/341667117/Subcentral-Mujeres-de-TIPNIS-Pronunciamiento-3-Marzo2017\#fullscreen\&from_embed>. Acesso em: 12 mai. 2017.

Porto, Jadson L. R. 2010. A condição periférico-estratégica da Amazônia Setentrional: a inserção do Amapá no Platô das Guianas In: Jadson L. R. Porto e Durbens M. Nascimento (orgs.). Interações fronteiriças no Platô das Guianas: novas construções, novas territorialidades. Rio de Janeiro: Publit, 139-160.

Raffestin, Claude. 1993. Por uma geografia do poder. São Paulo, Ática. 
Rosière, Stéphane. 2007. Géographie politique छ Géopolitique. Une grammaire de l'espace politique. $2^{\mathrm{e}}$ édition. Paris: Ellipses Édition.

Ruta Nacional 150: una de las mas complejas del pais. 2013. Revista Vial. Disponível em: $\quad<$ revistavial.com/index.php/publicaciones/2013/revista-94/item/1833ruta-nacional-150-una-de-las-mas-complejas-del-pais>. Acesso em: 12 jun. 2017.

Sampaio, Cristiane. 2018. Em visita ao Brasil, vice-presidente dos EUA busca aumentar a ofensiva contra Venezuela. Brasil de Fato. Brasília, 28 jun. 2018. Disponível em: <https://www.brasildefato.com.br/2018/06/28/em-visita-aobrasil-vice-presidente-dos-eua-busca-aumentar-ofensiva-contra-venezuela/ > . Acesso em: 30 ago. 2018.

Sanchez, Eugení. 1992. Geografía Política. Madrid: Editorial Síntesis.

Santos, Milton; Silveira, María Laura. 2003. O Brasil. Território e sociedade no início do século XXI. 5. ed., Rio de Janeiro: Record.

Scheibe, Eduarda F. 2013. Integração física e integração regional: a Iniciativa para Integração da Infraestrutura Regional Sul-Americana (IIRSA) como instrumento multiescalar de integração. Porto Alegre: POSGEA/UFRGS. 164 f. (Dissertação de Mestrado).

Silva, Gutemberg de V. 2014. Usos contemporâneos da fronteira franco-brasileira: entre os ditames globais e a articulação local. Macapá: Editora da Unifap.

Silva, Gutemberg de V.; Rückert, Aldomar A. 2009. A fronteira Brasil-França, Confins [Online], 7. Posto online em 31 out. 2009. Disponível em: <http://journals.openedition.org/confins/6040 ; DOI : 10.4000/confins.6040>. Acesso em: 26 nov. 2018.

Sistema Fiergs. Corredor Bioceânico Central ampliará logística para escoamento dos produtos gaúchos. Disponível em: <http://www.fiergs.org.br/pt-br/noticia/corredor-bioceanico-central-ampliara-logistica-para-escoamento-dos-produtos-gauchos>. Acesso em: 12 jun. 2017.

Spektor, Matias. 2017. Estilo ativista de José Serra enfrentou obstáculos. Folha de São Paulo. Ed. 24 fev. 2017. Disponível em: <http://www1.folha.uol.com. $\mathrm{br} /$ colunas/matiasspektor/2017/02/1861565-estilo-ativista-de-jose-serra-enfrentou-obstaculos.shtml> . Acesso em: 12 mai. 2017

Tola, Raúl. 2017. Ex-presidente do Peru Ollanta Humala é preso por corrupção no caso Odebrecht. El País. 14 jul. 2017. Disponível em: <https://brasil.elpais. $\mathrm{com} / \mathrm{brasil} / 2017 / 07 / 14 /$ internacional/1500001602_001817.html>. Acesso em: 25 jul. 2017. 
Uebel, Roberto G. 2015. Fronteras e inmigración contemporánea en Brasil: el caso de la inmigración boliviana. Mundi Migratios. 3, $\mathrm{n}^{\circ}$ 2, 92-111. Disponível em: $<$ www.anuariocemi.uh.cu/index.php/MMig/article/download/.../25>. Acesso em: 12 ago. 2017.

World Bank. 2017. GDP (current US\$). All countries and Economies. Disponível em: <https://data.worldbank.org/indicator/NY.GDP.MKTP.CD>. Acesso em: 21 ago. 2017. 


\section{NOTAS}

1. Este artigo contou com o apoio de recursos dos projetos de pesquisa "Políticas territoriais comparadas União Europeia-América do Sul" (CNPq) e "Transfronterizações na América do Sul. Dinâmicas territoriais, desenvolvimento regional, integração e defesa nas fronteiras meridional e setentrional do Brasil” (CAPES-Pró-Defesa). Foram desenvolvidas observações de campo pelos autores na região de Cuyo na Argentina e na Região das Guianas entre 2013 e 2017. A primeira versão do artigo, com o titulo "Quelle intégration de l'Amérique du Sud? Les infrastructures de liaison des régions périphériques et les tendances", foi publicada em francês no periódico online "Diploweb.com: Géopolitique, stratégie, relations internationales et cartes" no dia 25 fevereiro de 2018, e encontra-se disponível em: https://www.diploweb. com/Quelle-integration-de-l-Amerique-du-Sud-Les-infrastructuresde-liaison-des-regions-peripheriques-et.html.

2. Adota-se Região das Guianas para Amapá (BR), Guiana Francesa e Guiana, norte do Estado do Pará e Roraima (BR). Já Eixo do Escudo das Guianas é adotado pela IIRSA-Cosiplan para nomear o conjunto de obras previstas para a região.

3. "A política territorial se configura pelo conjunto de abordagens estratégicas, a médio e longo prazo, assim como pelas correspondentes formulações de atuação dirigidas a intervir sobre o território, a fim de que assuma as formas que sejam adequadas ao conjunto dos interesses que controlam o poder político”. (Sanchez 1992, 72).

4. Seminários e ateliês de cartografia temática foram desenvolvidos pelos grupos de pesquisa LABETER - Laboratório Estado e Território. Gestão, regiões e fronteiras, da Universidade Federal do Rio Grande do Sul e OBFRON - Observatório das Fronteiras, da Universidade Federal do Amapá, respectivamente em Porto Alegre (RS) e Macapá (AP) entre 2014 e 2018.

5. Governos populares liderados por Lula da Silva no Brasil, Néstor Kirchner na Argentina, Tabaré Vásquez no Uruguai, Evo Morales na Bolívia, Rafael Correa no Equador, Fernando Lugo no Paraguai e Hugo Chavez na Venezuela.

6. De acordo com os dados do Banco Mundial de 2016, os maiores contrastes do PIB estão entre o Brasil (US\$ 1,7 trilhões), a região dos Andes - como o Equador (US\$ 97,8 bilhões) e a Região das Guianas - , onde localizam-se os menores valores da América do Sul - na Guiana (US\$ 3,4 bilhões) e no Suriname (US\$ 3,6 bilhões). Já na Bacia do Prata os valores do PIB elevam-se na Argentina (US $\$ 545,8$ bilhões) e declinam no Paraguai (US $\$$ 27,4 bilhões) e no Uruguai (US\$ 52,4 bilhões) (World Bank). 
7. O Cosiplan adotou a regionalização dos projetos da IIRSA, em 9 Eixos de Integração e Desenvolvimento: Amazonas, Andino, Capricórnio, Sul, Escudo das Guianas, Hidrovia Paraná-Paraguai, Interoceânico, Mercosul-Chile e Peru-Bolívia-Brasil.

8. A Ruta Nacional 150 com 389,5 km é uma obra da Carteira de Projetos do Cosiplan, no grupo 4 Coquimbo-Região Centro Argentina Paysandú, do Eixo Mercosul-Chile, construída com fundos do tesouro argentino, concluída em 2015.

9. O projeto do Túnel Água Negra que consta dentre os 31 projetos da Agenda de Projetos Prioritários de Integração (API) da IIRSACosiplan visa consolidar uma rede de conectividade física com alcance regional. Ele consiste na construção de um túnel de 13,9 km no Andes na fronteira entre Argentina e Chile, que funcionará com como uma passagem alternativa ao Sistema Cristo Redentor. Conforme os termos do Cosiplan, devido à sua localização geográfica, conforma um importante eixo de integração regional que fortalece as conexões desde a zona central da Argentina até a área de influência do Porto de Coquimbo no Chile (Cosiplan, 2017, p. 155). A obra está prevista em US $\$ 1,6$ bilhão de dólares. A divulgação dos resultados de pré-qualificação para contratação de empresas para o projeto executivo, prevista para novembro de 2017, encontra-se, atualmente, postergada pela Entidade Binacional Túnel Água Negra (Ebitan).

10. O trecho rodoviário Boa Vista - Bonfim (BR 401, Roraima, Brasil) Lethem - Linden - Georgetown (República Cooperativa da Guiana) é outro dos 31 projetos estruturados da Agenda de Projetos Prioritários de Integração (API) da IIRSA-Cosiplan, pois se trata da única conexão viária entre os dois países. $\mathrm{O}$ asfaltamento previsto entre Lethem e Linden está orçado em US\$250 milhões, com data estimada de finalização para outubro de 2022. (Cosiplan, 2017, p. 138). Informações recentes apontam reuniões entre representantes dos governos da Guiana e do Brasil para preparar o projeto das obras que poderão iniciar ainda em 2018, com financiamento do Reino Unido, BID e China. (Chabrol 2018).

11. Regulamento (CE) n. ${ }^{\circ} 715 / 2007$, relativo à homologação dos veículos a motor no que diz respeito às emissões dos veículos ligeiros de passageiros e comerciais (Euro 5 e Euro 6). 


\section{AMÉRICA DO SUL: INFRAESTRUTURAS \\ EM REGIÕES PERIFÉRICAS ETENDÊNCIAS ATUAIS}

\section{RESUMO}

$\mathrm{O}$ artigo examina o regionalismo pós-neoliberal dos anos 2000 e o projeto sul-americano de uma região geopolítica e suas assimetrias internas; possíveis repercussões territoriais de projetos de redes de circulação em regiões periféricas e algumas tendências atuais da proposta como região geopolítica e das infraestruturas de conexão.

Palavras-chave: Políticas territoriais; América do Sul; Infraestruturas; Regiões periféricas.

\section{ABSTRACT}

The article deals with the post-neoliberal regionalism of the 2000 s and the South American project of a geopolitical region and its internal asymmetries; possible territorial repercussions of circulation network projects in peripheral regions and current trends of the proposal as a geopolitical region and the connection infrastructures.

Keywords: Territorial policies; South America; Infrastructures; Peripheral regions. 